\title{
Keragaan Varietas Kubis (Brassica oleracea L) Dataran Rendah dengan Aplikasi Mulsa di Maluku
}

\author{
Performances of Cabbage (Brassica oleracea L.) Varieties at a Lowland with Mulch \\ Application in Maluku
}

\section{Marietje Pesireron*, Sheny S. Kaihatu, Rein E. Senewe}

\author{
Balai Pengkajian Teknologi Pertanian (BPTP) Maluku, Jln. Chr. Soplanit Rumahtiga Ambon, 97233 Indonesia \\ *E-mail Penulis Korespondensi: itjepesi@yahoo.com
}

Tanggal submisi: 25 November 2019; Tanggal penerimaan: 26 Mei 2020

\begin{abstract}
The low yield of cabbage in Maluku is thought to due to the lack of attention of farmers to grow to crop because so far farmers think it can only grow well and forms crops in the highlands, so no one wants to grow cabbage. This study aimed to determine the yield performance of five cabbage varieties with the use of several types of mulches and was carried out in Gemba Village, Kairatu Subdistrict, Western Seram Regency. The experimental design used was the factorial Randomized Block Design with three replications and the farmers as replications. The first factor was five varieties of cabbage (Sehati-F1, Daehnfeldt, Green Hero, Green Coronet, KK-Koss), the second factor was the type of mulch, consisting of four types, namely: without mulch (MO), black silver plastic mulch, straw mulch, and husk mulch. The data obtained were analyzed with analysis of variance and DMRT test at the level of 5\% if necessary. Parameters observed included plant height at 45 days after planting, leaf number, percentage of crop formation, percentage of pest and disease attacks, crop circumference per plant at harvest, fruit weight, and yield. The study results showed that the five varieties tested with the use of various types of mulch had the potentials to be developed in Maluku. Varieties with the highest yields and very good adaptation to lowland environments in Maluku included Sehati-F1 and KK-Cross. Pest control by using plant-based pesticides in a combination with scheduled mechanical control (yellow plates, pitfalls, and stick traps) could reduce the levels of pest and disease attacks and the crops appeared healthy for consumption.
\end{abstract}

Keywords: cabbage, lowland, mulch

\section{ABSTRAK}

Rendahnya produksi kubis di Maluku diduga akibat kurangnya perhatian petani untuk bertanam kubis, yang dikarenakan selama ini petani mengira kubis hanya dapat tumbuh baik dan membentuk krop di dataran tinggi, sehingga sedikit petani yang mau berusahatani kubis. Kajian ini bertujuan mengetahui keragaan hasil lima varietas kubis dengan penggunaan berbagai jenis mulsa di desa Gemba, Kecamatan Kairatu, Kabupaten Seram Bagian Barat. Rancangan percobaan yang digunakan adalah rancangan acak kelompok faktorial dengan tiga ulangan dan petani sebagai ulangan. Faktor pertama adalah lima varietas kubis (Sehati-F1, Daehnfeldt, Green hero, Green Coronet, KK-Cross); faktor kedua adalah jenis mulsa yang terdiri dari empat macam, yaitu: tanpa mulsa (M0), mulsa plastic hitam perak, mulsa jerami dan mulsa sekam. Data yang diperoleh dianalisis menggunakan analisis ragam dan uji lanjut DMRT pada taraf 5\% sesuai kebutuhan. Peubah-peubah yang diamati meliputi tinggi tanaman umur 45 hari setelah tanam (hst), jumlah daun, persentase pembentukan krop, persentase serangan hama dan penyakit, lingkar buah per tanaman saat panen, bobot buah dan hasil panen. Hasil penelitian menunjukkan bahwa kelima varietas yang di uji dengan penggunaan berbagai jenis mulsa sangat berpotensi untuk dibudidayakan di Maluku berdasarkan kemampuannya membentuk krop. Varietas dengan produksi tertinggi dan beradaptasi sangat baik terhadap lingkungan dataran rendah di lokasi penelitian adalah Sehati-F1 dan KK-Cross. Penggendalian hama dengan menggunakan pestisida nabati yang dikombinasikan dengan pengendalian secara mekanis (tampan kuning, pitfoll dan sticky trap) secara terjadwal dapat menurunkan tingkat serangan hama dan penyakit, dan menghasilkan tanaman-tanaman yang sehat.

Kata Kunci: dataran rendah, kubis, mulsa, varietas 


\section{PENDAHULUAN}

Budidaya kubis awalnya dilakukan di daerah dataran tinggi, namun dalam perkembangannya sekarang sudah ada kubis dataran menengah bahkan dataran rendah (Pracaya, 2001 dalam Ridwan et al., 2013). Budidaya tanaman hortikultura dataran tinggi saat ini rentan terhadap kerusakan lingkungan karena pembukaan lahan baru tidak memperhatikan aspekaspek konservasi, sedangkan daerah dataran rendah umumnya memiliki suhu cukup tinggi dibanding dataran tinggi sehingga diperlukan varietas kubis untuk dataran rendah dan memanipulasi iklim mikro disekitar tanaman. Salah satu cara yaitu menggunakan mulsa. Mulsa merupakan material penutup tanaman untuk menjaga kelembaban tanah, menekan pertumbuhan gulma dan penyakit. Pemakaian mulsa juga dapat mengurangi pemanasan langsung, suhu tanah meningkat dan air tidak hilang karena evaporasi tertahan oleh mulsa yang menyebabkan lembabnya permukaan tanah sehingga membuat tanaman tersebut tumbuh dengan baik (Suhardjo, 1993 dalam Ridwan et al. (2013).

Luas panen dan produksi kubis di Maluku masih sangat rendah, jika dibandingkan dengan propinsi lain. Data menunjukkan bahwa produksi kubis di Maluku selama 5 tahun terakhir adalah 1.299 ton dengan luas panen 168 hektar dan provitas 7,73 ton/ha (SPH, 2014). Sedangkan pada tahun 2014, luas panen kubis di Maluku hanya 155 ha dengan produksi hanya 1087 ton (Maluku, 2015).

Rendahnya hasil produksi kubis di Maluku disebabkan karena teknologi budidaya yang diterapkan belum optimal dan hanya ditanam untuk konsumsi sendiri dan sangat terbatas selain itu belum menggunakan varietas unggul baru/hibrida, pupuk yang belum berimbang, pengendalian hama penyakit dan gulma belum optimal, sistem dan jarak tanam yang belum tepat, pengetahuan petani tentang informasi dan keberadaan varietas unggul baru sangat kurang serta kurangnya sosialisasi dan ketersediaan benih bermutu serta kondisi ekosistem tanaman sehingga tidak memacu berkembangnya hama dan penyakit tanaman (Sastrosiswojo et al., 2003). Sifat mudah rusak kubis disebabkan oleh daun yang lunak dan kandungan air cukup tinggi, sehingga mudah ditembus oleh alat-alat pertanian dan hama/penyakit tanaman.

Menurut Rukmana (2005) dalam Erwin et al. (2015) bahwa pengaturan kerapatan sangat berpengaruh terhadap pertumbuhan tanaman kubis bunga terutama pada masa pembentukan bunga dengan memanfaatkan cahaya secara efektif dan penyebaran unsur hara secara merata. Intensitas cahaya yang diberikan pada tanaman kubis bunga dataran tinggi yang ditanam pada dataran rendah juga sangat berpengaruh terhadap pertumbuhan tanaman.

Dataran rendah umumnya memiliki suhu cukup tinggi dibanding dataran tinggi hingga diperlukan upaya pengembangan kubis dataran rendah dengan menggunakan varietas dataran rendah dan memanipulasi iklim mikro disekitar tanaman. Salah satu cara adalah dengan menggunakan mulsa. Mulsa merupakan material penutup tanaman untuk menjaga kelembaban tanah, menekan pertumbuhan gulma dan penyakit. Mulsa dapat mengurangi pemanasan langsung, suhu tanah tidak naik dan air tidak hilang karena evaporasi tertahan mulsa dan menyebabkan permukaan tanah lembab dan tanaman tumbuh dengan baik (Suhardjo, 1993 dalam Ridwan et al., 2013).

Penelitian ini bertujuan untuk mengetahui keragaan hasil lima varietas kubis dataran rendah terhadap penggunaan berbagai jenis mulsa di desa Gemba Kecamatan Kairatu Kabupaten Seram Bagian Barat (SBB).

\section{BAHAN DAN METODE}

\section{Waktu dan Tempat}

Penelitian ini merupakan percobaan lapang, yang dilakukan di lahan petani di desa Gembah Kecamatan Kairatu, Kabupaten SBB mulai dari Februari sampai dengan Agustus 2016, dengan melibatkan petani secara partisipatif. Untuk mendapatkan informasi budidaya kubis di tingkat petani dilakukan PRA dan survai calon petani dan calon lokasi dengan melibatkan beberapa petani dan PPL sebagai sumber informasi. Data dan informasi yang diperoleh digunakan sebagai data dasar dalam pelaksanaan kegiatan.

\section{Bahan yang Digunakan}

Lima varietas kubis adalah: Sehati-F1, Daehnfieldt, Green hero, Green Coronet, dan KKCross). Jenis mulsa yang digunakan ada tiga yakni Mulsa hitam perak, Sekam padi, dan Jerami padi.

Penelitian dilaksanakan menggunakan rancangan acak kelompok disusun secara faktorial yang diulang tiga kali. Faktor pertama adalah varietas (V) dengan lima varietas kubis yaitu V1 = Sehati-F1, V2 = Daehnfeldt, V3 = Green hero, V4 = Green Coronet, dan V5 = KK-Cross. Faktor kedua adalah mulsa dengan tiga macam yaitu $\mathrm{M} 0=$ Kontrol, $\mathrm{M} 1=$ mulsa hitam perak, $\mathrm{M} 2$ = jerami padi dan $\mathrm{M} 3=$ sekam padi. Jumlah kombinasi perlakuan adalah 20 , dan setiap kombinasi diulang 3 kali sehingga ada 60 petak percobaan. Data yang diperoleh selama pengamatan, dianalisis dengan analisis ragam dan apabila terdapat perbedaan antara perlakuan maka dilanjutkan dengan uji beda nyata terkecil (BNT) $5 \%$.

Ukuran bedengan $1,5 \mathrm{~m} \times 25 \mathrm{~m}$ untuk setiap perlakuan dengan jarak tanam $55 \mathrm{~cm} \times 50 \mathrm{~cm}$. Pembuatan bedengan bersamaan dengan pemberian pupuk organik cair $3 \mathrm{~L} / \mathrm{ha}$ dan NPK phonska dengan dosis $250 \mathrm{~kg} / \mathrm{ha}$. Kebutuhan benih 200-250 g/ha. Penggendalian hama secara mekanis dengan cara pemasangan tampan kuning, pitfall trap yang diisi dengan air sabun dan sticky treep (insect glow) yang di lakukan setiap hari yaitu jika pagi atau sore di letakkan besok pagi atau sore hari diganti lagi secara bersamaan di tiap lahan petani 


\section{Komponen Pengamatan tanaman meliputi}

Pengamatan dilakukan terhadap tanaman sampel pada setiap petak percobaan yang meliputi komponen pertumbuhan dan komponen hasil berupa peubah yang diamati, meliputi tinggi tanaman $45 \mathrm{hst}$, jumlah daun umur 45 hst, persentase pembentukan krop 45 hst, persentase serangan hama ulat daun, persentase serangan hama krop, lingkar buah per tanaman saat panen, bobot buah per tanaman saat panen, dan produksi (ton/ha).

\section{HASIL DAN PEMBAHASAN}

\section{Tinggi Tanaman}

Tinggi tanaman adalah ukuran panjang batang tanaman yang diukur sebagai indikator pertumbuhan. Tinggi tanaman merupakan ukuran tanaman yang sering diamati sebagai indicator pertumbuhan (Sitompul dan Guritno, 1995 dalam Anni et al., 2013).

Hasil analisis ragam menunjukkan adanya interaksi antara varietas dengan mulsa terhadap tinggi tanaman kubis. Jenis mulsa berpengaruh sangat nyata terhadap tinggi tanaman kubis pada umur 45 hst. Hasil analisis BNT menunjukkan adanya pertambahan tinggi tanaman pada umur 45 hst pada perlakuan Mulsa Plastik Hitam Perak (MPHP) (M1) dengan rerata tinggi tanaman 24,97 $\mathrm{cm}$ dibanding perlakuan lain yaitu tanpa mulsa (M0), mulsa jerami (M2) dan mulsa sekam (M3). Terdapat interaksi dan pengaruh kedua perlakuan terhadap tinggi tanaman pada umur 45 hst. Pada peubah tinggi tanaman umur 45 hst, varietas Green hero yang tertinggi $(29,8 \mathrm{~cm})$ dengan penggunaan MPHP namun tidak berbeda nyata dengan varietas yang lainnya namun, pada penggunaan mulsa jerami (M2) tinggi tanaman tertinggi adalah varietas Daehnfieldt $(28,1 \mathrm{~cm})$ namun tidak berbeda dengan varietas varietas yang lain. Sedangkan penggunaan mulsa sekam padi tidak memberikan perbedaan antara empat varietas yaitu Green Hero, Green Coronet dan KK-Cross sedangkan berbeda nyata Sehati-F1 dan Daehnfeldt (Tabel 1). Rerata tinggi tanaman terendah adalah varietas KKCross pada semua perlakuan mulsa. Ini menunjukkan bahwa kerapatan penutup tanah pada awal pertumbuhan akan mempengaruhi tanaman memperoleh cahaya untuk proses metabolisme tanaman, terutama proses pembentukkan sel-sel tanaman (anabolisme) untuk pertumbuhan tanaman (Ridwan et al., 2013). Mulsa sekam padi merupakan mulsa organik yang dapat memperbaiki struktur dan sifat tanah sehingga pertumbuhan tanaman kubis bisa mencapai optimum (Rahmawati et al., 2011).

\section{Jumlah Daun}

Proses pertumbuhan tanaman kubis sangat dipengaruhi faktor internal (bahan tanam) dan faktor eksternal (lingkungan). Faktor lingkungan yang mempengaruhi pertumbuhan tanaman adalah antara lain iklim, tanah, cuaca, pH tanah, intensitas cahaya matahari dan gangguan hama penyakit. Sementara peranan jarak tanam dalam pertumbuhan tanaman adalah untuk menjaga adanya persaingan dalam perebutan makanan (unsur hara) yang diperlukan setiap individu tanaman. Prawitasari (2003) dalam Erwin et al. (2015) menjelaskan bahwa perubahan pertumbuhan kearah perkembangan hasil tanaman dipengaruhi oleh kemampuan kerja enzim dalam tubuh tanaman dan faktor lingkungan. Pertumbuhan dan perkembangan organ ditentukan oleh suatu proses yang dinamakan fotosintesis bila hasilnya baik maka akan menghasilkan pertumbuhan dan perkembangan tanaman yang baik pula, hal ini dapat terukur pada penambahan jumlah organ tanaman, perluasan sel-sel dan proses fotosintesis dapat berjalan dengan baik bila faktor (hara, suhu dan udara) yang mempengaruhi proses tersebut berada pada kondisi optimum (Willy, 1998) dalam Erwin et al. (2015).

Hasil analisis BNT menunjukkan tidak adanya perbedaan jumlah daun pada semua perlakuan mulsa. Rerata jumlah daun pada semua perlakuan mulsa tertinggi adalah penggunaan mulsa Plastik Hitam Perak dan mulsa jerami, sedangkan rerata jumlah daun yang paling sedikit adalah tanpa menggunakan mulsa. Pada peubah jumlah daun umur 45 hst, jumlah daun terbanyak diperoleh varietas Green hero (16 helai) dengan penggunaan mulsa Plastik Hitam Perak dan yang paling sedikit adalah varietas Daehnfieldt (13 helai) pada perlakuan tanpa mulsa (Tabel 2).

Tabel 1. Rerata tinggi Tanaman $(\mathrm{cm})$ kubis pada umur 45 hst

\begin{tabular}{cccccc}
\hline & \multicolumn{5}{c}{ Tinggi Tanaman 45 hst } \\
\cline { 2 - 5 } Perlakuan Mulsa & Sehati-F1 & Daehnfeldt & Green hero & Green Coronet & KK-Cross \\
\cline { 2 - 6 } & $23,93 \mathrm{a}$ & $25,15 \mathrm{~b}$ & $28,25 \mathrm{a}$ & $23 \mathrm{a}$ & $20 \mathrm{a}$ \\
\hline Tanpa mulsa & $25,4 \mathrm{a}$ & $26,65 \mathrm{a}$ & $29,8 \mathrm{a}$ & $24 \mathrm{a}$ & $19 \mathrm{a}$ \\
MulsaHitam Perak & $23,4 \mathrm{a}$ & $28,1 \mathrm{a}$ & $26,2 \mathrm{a}$ & $23,7 \mathrm{a}$ & $20 \mathrm{a}$ \\
Jerami Padi & $22,83 \mathrm{~b}$ & $24,74 \mathrm{~b}$ & $24,6 \mathrm{a}$ & $22,5 \mathrm{a}$ & $20,3 \mathrm{a}$ \\
Sekam Padi & 2,15 & 2,23 & 3,7 & 2,1 & 1,4 \\
\hline KK $(\mathbf{C V}) \%$ & $\%$ &
\end{tabular}


Tabel 2. Rerata jumlah daun tanaman kubis pada umur 45 hst

\begin{tabular}{cccccc}
\hline \multirow{2}{*}{ Perlakuan Mulsa } & \multicolumn{5}{c}{ Jumlah Daun (45 hst) } \\
\cline { 2 - 6 } & Sehati-F1 & Daehnfieldt & Green hero & Green Coronet & KK-Cross \\
\cline { 2 - 6 } & $15 \mathrm{a}$ & $13 \mathrm{a}$ & $15 \mathrm{a}$ & $14 \mathrm{a}$ & $14 \mathrm{a}$ \\
Tanpa mulsa & $15 \mathrm{a}$ & $15 \mathrm{a}$ & $16 \mathrm{a}$ & $14 \mathrm{a}$ & $14 \mathrm{a}$ \\
Mulsa Hitam Perak & $15 \mathrm{a}$ & $14 \mathrm{a}$ & $15 \mathrm{a}$ & $15 \mathrm{a}$ & $15 \mathrm{a}$ \\
Jerami Padi & $14 \mathrm{a}$ & $14 \mathrm{a}$ & $14 \mathrm{a}$ & $15 \mathrm{a}$ & $15 \mathrm{a}$ \\
Sekam Padi & 1,2 & 1,2 & 2,1 & 1,5 & 1.3 \\
\hline KK $(\mathbf{C V}) \%$ & &
\end{tabular}

Keterangan: Angka yang didampingi huruf sama pada kolom yang sama, tidak berbeda nyata pada uji BNT 5\%.

Hal ini disebabkan karena masing-masing varietas kubis mempunyai bentuk morfologi yang berbeda. Menurut Harjadi (1998) dalam Hayati et al. (2012) bahwa setiap varietas tanaman mempunyai sifat genotip yang berbeda, yang mempengaruhi sifat fenotipe yang muncul akibat berinteraksi dengan lingkungan. Daun merupakan komponen utama pada tumbuhan yang berperan dalam proses fotosintesis. Pada daun terdapat klorofil (zat hijau daun), dimana zat inilah yang akan menyerap energi matahari sehingga dapat dimanfaatkan untuk menghasilkan nutrisi. Buntoro et al. (2014) menyatakan bahwa daun berperan untuk menangkap cahaya dan merupakan tempat berlangsungnya proses fotosintesis. Perkembangan jumlah daun juga akan mempengaruhi perkembangan tanaman. Semakin banyak daun dapat diartikan semakin banyak cahaya yang dapat ditangkap sehingga proses fotosintesis akan meningkat. Meningkatnya proses fotosintesis pada tanaman berpengaruh terhadap hasil yang diperoleh. Selanjutnya menurut Gardner et al. (1991) dalam Ramli (2010) bahwa peningkatan luas daun dalam penyerapan $\mathrm{CO}_{2}$ untuk fotosintesis ditunjang oleh struktur daun yang ideal walaupun dalam kondisi tekanan lingkungan merupakan kemampuan suatu tanaman beradaptasi agar tetap lestari.

\section{Persentase Pembentukan Krop}

Rerata persentase pembentukkan krop pada umur 45 hst berkisar antara 32-40\% untuk semua perlakuan mulsa. Hasil uji BNT menunjukkan bahwa varietas Green Coronet, dan KK-Cross untuk semua perlakuan mulsa tidak ada perbedaan nyata sama halnya dengan varietas Green Hero dimana ke tiga perlakuan mulsa (mulsa hitam perak, mulsa jerami padi dan mulsa sekam padi) tidak berbeda nyata namun berbeda nyata dengan perlakuan tanpa mulsa (M0). Varietas Sehati-F1 untuk perlakuan tanpa mulsa (M0), perlakuan hitam perak (M1) dan perlakuan mulsa sekam padi (M3) tidak berbeda nyata namun berbeda nyata dengan perlakuan mulsa jerami padi (M2). Selanjutnya varietas Daehnfeldt tidak terjadi perbedaan nyata antara perlakuan tanpa mulsa (M0) dan perlakuan mulsa jerami padi (Tabel 3). Presentase pembentukkan krop tertinggi pada umur 45 hst adalah varietas Daehnfeldt dan varietas Green hero, sebanyak $40 \%$ dan paling sedikit pembentukkan krop adalah perlakuan M3 (mulsa sekam) varietas Sehati-F1 yaitu 32\% pada penggunaan mulsa jerami (M2). Pembentukan krop yang lebih cepat dapat menentukan waktu panen lebih cepat juga, hal ini dapat terjadi kerena interaksi genotipe dan lingkungan. Menurut Prawitasari (2003) dalam Ramli (2010) bahwa dalam kondisi tanpa mulsa, kebutuhan suhu lingkungan tanaman diduga sangat berkaitan dengan kandungan senyawa-senyawa endogen dan perubahan faktor lingkungan. Faktor lingkungan yang paling mempengaruhi pertumbuhan kubis ialah suhu. Kisaran suhu siang hari untuk pertumbuhan kubis dataran rendah yaitu antara $26-29^{\circ} \mathrm{C}$. Pada kisaran suhu tersebut, kubis dataran rendah masih toleran dalam mendukung pertumbuhan dan hasil yang baik (Subhan, 1995 dalam Sumarni et al., 2006).

Penampakan suatu varietas akibat pengaruh lingkungan lebih disebabkan oleh lingkungan mikro tanaman dan sifat ini disebut sebagai sifat kuantitatif (Puspodarsono, 1988 dalam Ridwan et al., 2013). Hasil penelitian Nathoo, Nowbuth dan Cangy (1998) pada KK-Cross yang ditanam pada daerah dengan iklim antara $18,6-26,9^{\circ} \mathrm{C}$ mencapai berat $2,52 \mathrm{~kg} / \mathrm{krop}$.

Tabel 3. Persentase pembentukan krop tanaman kubis pada umur 45 hari setelah tanam (hst)

\begin{tabular}{cccccc}
\hline \multirow{2}{*}{ Perlakuan Mulsa } & \multicolumn{5}{c}{ Pembentukan krop pada umur (45 hst) } \\
\cline { 2 - 5 } & Sehati-F1 & Daehnfeldt & Green hero & Green Coronet & KK-Cross \\
\cline { 2 - 6 } & $36 \mathrm{a}$ & $40 \mathrm{a}$ & $36 \mathrm{~b}$ & $35 \mathrm{a}$ & $35 \mathrm{a}$ \\
Tanpa mulsa (M0) & $36 \mathrm{a}$ & $35 \mathrm{~b}$ & $40 \mathrm{a}$ & $35 \mathrm{a}$ & $34 \mathrm{a}$ \\
Mulsa hitam perak (M1) & $32 \mathrm{~b}$ & $38 \mathrm{a}$ & $40 \mathrm{a}$ & $35 \mathrm{a}$ & $35 \mathrm{a}$ \\
Jerami padi (M2) & $34 \mathrm{a}$ & $34 \mathrm{~b}$ & $40 \mathrm{a}$ & $34 \mathrm{a}$ & $35 \mathrm{a}$ \\
Sekam padi (M3) & 3.2 & 4,3 & 3,1 & 2,6 & 2,8 \\
\hline KK(CV) \% & &
\end{tabular}

Keterangan: Angka yang didampingi huruf sama pada kolom yang sama, tidak berbeda nyata pada uji BNT 5\%. 


\section{Persentase Serangan Hama Ulat Daun}

Hasil analisis BNT menunjukkan adanya perbedaan serangan hama daun pada umur 65 hst pada semua perlakuan mulsa. Persentase tingkat serangan hama tertinggi yaitu pada perlakuan M0 (tanpa mulsa) terjadi pada varietas Sehati-F1 $(42,3 \%)$ sedangkan terendah pada perlakuan M1 (Mulsa Plastik Hitam Perak) terjadi pada varietas KK-Cross (15\%). Tingginya persentase serangan hama sangat ditentukan oleh intensitas curah hujan pada saat umur tanaman memasuki masa panen yaitu $65 \mathrm{hst}$, intensitas serangan hama ulat daun (Plutella Cilustella) cukup tinggi (1542,3\%) namun karena tanaman semua sudah membentuk krop dan rata-rata cukup bagus karena mulai dari umur tanaman 10-65 hst dilakukan pengendalian secara mekanis yaitu penggunaan stiky treep, pitfoll, light treep dan dikombinasi dengan penyemprotan pestisida nabati secara terjadwal 3 kali seminggu. Sementara menurut (Simon et al., 2014) populasi $P$. xylostella dan Helulla undalis sangat tertekan pada budidaya kubis di dalam rumah kasa. Menurut (Martin et al., 2006), penggunaan rumah kasa mampu mengurangi infestasi $H$. undalis dan $P$. xylostella masing-masing sebesar $88 \%$ dan $78 \%$ serta mengurangi aplikasi pestisida sebanyak 3-10 kali. Hasil penelitian Laksminiwati et al. (2017) menunjukkan bahwa penggunaan rumah kasa mampu menekan populasi ulat daun kubis dan kerusakan tanaman oleh serangan ulat krop kubis, sehingga dapat mengurangi jumlah aplikasi insektisida sebesar $62,50 \%$, dengan hasil panen lebih tinggi sebesar
13,75\% dan kualitas krop kubis tetap tinggi yang ditunjukkan oleh nilai kadar serat sebesar $0,88 \%$ dan kekerasan krop sebesar 3,89 m/detik/100 g. Keefektifan penggunaan rumah kasa juga dilaporkan oleh (Neave et al., 2011) mampu mengurangi kerusakan tanaman kubis sebesar $38-72 \%$.

\section{Persentase Serangan Hama krop}

Serangan utama Crocidolomia binotalis Zell yaitu pada bagian dalam yang terlindungi daun hingga mencapai titik tumbuh. Kalau serangan ini ditambah lagi dengan serangan penyebab penyakit, tanaman bisa mati karena bagian dalamnya menjadi busuk meskipun dari luar kelihatannya masih baik (Santosa dan Sartono, 2007). Selanjutnya menurut (Badjo et al., 2015) bahwa serangan hama krop larva instar awal memakan daun dan meninggalkan lapisan epidermis yang kemudian berlubang lubang setelah lapisan epidermis tersebut mengering. Pengamatan lapangan menunjukkan bahwa apabila larva telah berukuran lebih besar maka akan menyerang krop. Krop kubis yang terserang memperlihatkan banyak kotoran yang merupakan faces dari larva, dan krop tersebut nampak berlubang-lubang. Ulat krop dikenal sebagai hama yang sangat rakus secara berkelompok dapat menghabiskan seluruh daun dan hanya meninggalkan tulang daun saja. Pada populasi tinggi terdapat kotoran berwarna hijau bercampur dengan benang-benang sutera. Ulat krop juga masuk dan memakan krop sehingga tidak dapat dipanen sama sekali (Ahmad, 2007).

Tabel 4. Persentase tingkat serangan hama ulat daun (\%) 65 hst

\begin{tabular}{cccccc}
\hline \multirow{2}{*}{ Perlakuan Mulsa } & \multicolumn{5}{c}{ Persentase tingkat serangan hama ulat daun (65 hst) } \\
\cline { 2 - 6 } & Sehati-F1 & Daehnfeldt & Green hero & Green Coronet & KK-Cross \\
\cline { 2 - 6 } & $42,3 \mathrm{a}$ & $37,3 \mathrm{a}$ & $33,2 \mathrm{a}$ & $36,7 \mathrm{a}$ & $25 \mathrm{a}$ \\
Tanpa mulsa & $30,3 \mathrm{c}$ & $25,3 \mathrm{~d}$ & $20,5 \mathrm{c}$ & $29,8 \mathrm{~b}$ & $15 \mathrm{~d}$ \\
Mulsa Hitam Perak & $33,5 \mathrm{~b}$ & $27,8 \mathrm{~d}$ & $20.8 \mathrm{c}$ & $31,2 \mathrm{~b}$ & $22,3 \mathrm{a}$ \\
Jerami padi & $37,4 \mathrm{~b}$ & $30,2 \mathrm{c}$ & $21,7 \mathrm{c}$ & $34,2 \mathrm{a}$ & $21,1 \mathrm{~b}$ \\
Sekam padi & 4,2 & 3,7 & 4,4 & 3,6 & 3,1 \\
\hline KK(CV) \% & &
\end{tabular}

Keterangan: Angka yang didampingi huruf sama pada kolom yang sama, tidak berbeda nyata pada uji BNT 5\%.

Tabel 5. Persentase tingkat serangan hama krop (\%) 65 hst

\begin{tabular}{cccccc}
\hline & \multicolumn{5}{c}{ Persentase tingkat serangan hama krop 65 (hst) } \\
\cline { 2 - 6 } Perlakuan Mulsa & \multicolumn{5}{c}{ Varietas } \\
\cline { 2 - 6 } & Sehati-F1 & Daehnfeldt & Green hero & Green Coronet & KK-Cross \\
\hline Tanpa mulsa & $25 \mathrm{a}$ & $15 \mathrm{c}$ & $20 \mathrm{~d}$ & $13 \mathrm{a}$ & $10 \mathrm{~b}$ \\
Mulsa hitam perak & $20 \mathrm{~b}$ & $25 \mathrm{a}$ & $\mathbf{3 5} \mathrm{a}$ & $15 \mathrm{a}$ & $13 \mathrm{a}$ \\
Jerami padi & $20 \mathrm{~b}$ & $15 \mathrm{c}$ & $15 \mathrm{e}$ & $13 \mathrm{a}$ & $12 \mathrm{a}$ \\
Sekam padi & $15 \mathrm{c}$ & $10 \mathrm{~d}$ & $20 \mathrm{~d}$ & $10 \mathrm{~b}$ & $10 \mathrm{~b}$ \\
\hline KK(CV)\% & 3,1 & 3,8 & 3,5 & 2,7 & 1,4 \\
\hline
\end{tabular}

Keterangan: Angka yang didampingi huruf sama pada kolom yang sama, tidak berbeda nyata pada uji BNT 5\%. 
Ulat ini biasanya ditandai dengan adanya kumpulan kotoran pada daun kubis dan krop menjadi berlubang-lubang yang menyebabkan kualitas hasil panennya menurun. Serangan utama ( $C$. binotalis Zell) yaitu pada bagian dalam yang terlindungi daun hingga mencapai titik tumbuh. Kalau serangan ini ditambah lagi dengan serangan penyebab penyakit, tanaman bisa mati karena bagian dalamnya menjadi busuk meskipun dari luar kelihatannya masih baik (Santosa dan Sartono, 2007).

Tanaman kubis mengalami serangan hama krop (C. binotalis) berkisar antara $(10-35 \%)$. Hasil analisis BNT menunjukkan adanya perbedaan persentase serangan hama krop pada umur 65 hst pada semua perlakuan. Persentase tingkat serangan yang paling tinggi ditunjukkan oleh Varietas Green Hero (35\%) pada perlakuan mulsa hitam perak dan sangat berbeda nyata dengan perlakuan mulsa dan varietas yang lain. Sedangkan tingkat serangan yang paling rendah ditunjukkan oleh varietas Daehnfieldt, Green Hero dan KK-Cross pada perlakuan mulsa sekam padi dan sangat berbeda nyata pada perlakuan mulsa dan varietas yang lain (Tabel 5).

Daun yang telah dirusak oleh ulat krop bagaikan teranyam, terlihat jelas bekas gigitan yang membuat daun berlubang, kerusakan dimulai dari permukaan daun sebelah bawah. Serangan berat biasanya terlihat tulang daun saja (Herwibowo dan Budiana, 2014). Hama $C$. binotalis Zell merupakan hama utama yang sulit di kendalikan secara kimiawi, karena jika secara terus menerus dikendalikan dengan insektisida sintetik, hama utama kubis tersebut semakin resisten terhadap insektisida yang umum digunakan petani (Tang et al., 2008).

\section{Lingkar Buah Per Tanaman Saat Panen}

Hasil analisis BNT menunjukkan adanya perbedaan lingkar buah per tanaman saat panen pada semua perlakuan mulsa. Lingkar buah krop kubis dari kelima varietas yang diuji mencapai kondisi yang cukup maksimal berkisar antara 39,3 cm - 61,7cm. Lingkar krop kubis yang terbesar ditunjukkan oleh varietas Daenhnfieldt pada perlakuan mulsa jerami padi $(61,7$ $\mathrm{cm})$ sedangkan yang terkecil ditunjukkan oleh varietas green Hero dengan perlakuan tanpa mulsa $(39,3 \mathrm{~cm})$.
Besarnya lingkar buah/krop tanaman kubis dengan penggunaan mulsa jerami padi disebabkan karena jerami cepat menjadi kompos dan dapat meningkatkan kesuburan tanah hal ini sangat berpengaruh terhadap pembentukan krop tanaman kubis. Hal ini terjadi karena penggunaan mulsa jerami yang bersifat organik dan memiliki pori-pori mampu menjaga aerasi serta kosistensi mengeluarkan suhu panas dalam tanah sehingga keadaan tanah lebih hangat ketika suhu lingkungan tinggi dan tetap hangat ketika suhu lingkungan rendah, keadaan tersebut akan membuat akar tanaman lebih optimal dalam menyerap unsur hara saat fase generative (Laksono, 2016).

\section{Bobot Buah Per Tanaman Saat Panen}

Hasil analisis BNT menunjukkan tidak ada perbedaan bobot buah saat panen semua perlakuan mulsa. Rerata bobot tertinggi diperoleh pada perlakuan mulsa jerami dan bobot terendah pada perlakuan tanpa mulsa. Bobot tertinggi adalah varietas Sehati-F1, varietas KK-Cross pada perlakuan mulsa jerami dan mulsa sekam padi yaitu $1,2 \mathrm{~kg}$. Hal ini disebabkan karena varietas Sehati-F1 dan KK-Cross lebih cocok dibudidayakan di dataran rendah dibandingkan dengan varietas lain yang lebih cocok dibudidayakan didaerah dataran tinggi, walaupun hasil yang diperoleh ke dua varietas itu, masih jauh lebih rendah dari potensi yang dimiliki varietas tersebut.

Menurut Ramli (2010) tanaman kubis varietas KS-Cross dan KK-Cross yang tumbuh di dataran rendah bobot segar krop sebesar 1086,11 g dan $955 \mathrm{~g}$, sedangkan bobot segar krop yang berat ada pada perlakuan tanpa mulsa dan mulsa jerami sebesar $1002,67 \mathrm{~g}$ dan $885 \mathrm{~g}$. Hal ini sesuai dengan pendapat Simatupang (1997) dalam (Marliah et al., 2010) bahwa tingginya hasil suatu varietas dikarenakan varietas tersebut mampu beradaptasi dengan lingkungan. Meskipun secara genetik varietas lain mempunyai potensi hasil yang baik, tetapi masih dalam tahap adaptasi, maka hasilnya lebih rendah daripada yang seharusnya. Menurut (Salisbury dan Ross, 1995) bahwa setiap varietas memiliki ketahanan yang berbeda-beda, beberapa tanaman dapat melakukan adaptasi dengan cepat, namun sebaliknya ada tanaman yang membutuhkan waktu lama untuk dapat beradaptasi dengan lingkungan.

Tabel 6. Rerata lingkar buah tanaman kubis (cm)

\begin{tabular}{cccccc}
\hline \multirow{2}{*}{ Mulsa } & \multicolumn{5}{c}{ Lingkar Buah Saat Panen $(\mathrm{Cm})$} \\
\cline { 2 - 6 } & Sehati-F1 & Daehnfeldt & Green hero & Green Coronet & KK-Cross \\
\hline Tanpa mulsa & $43,5 \mathrm{e}$ & $49 \mathrm{~d}$ & $\mathbf{3 9 , 3} \mathbf{f}$ & $48 \mathrm{~b}$ & $49 \mathrm{~b}$ \\
Mulsa hitam perak & $54 \mathrm{a}$ & $46,8 \mathrm{e}$ & $41,6 \mathrm{e}$ & $53 \mathrm{a}$ & $51 \mathrm{a}$ \\
Jerami padi & $53,9 \mathrm{a}$ & $\mathbf{6 1 , 7} \mathbf{a}$ & $45,5 \mathrm{~d}$ & $54 \mathrm{a}$ & $53,5 \mathrm{a}$ \\
Sekam padi & $50 \mathrm{~b}$ & $50 \mathrm{~d}$ & $57,9 \mathrm{a}$ & $53,5 \mathrm{a}$ & $54 \mathrm{a}$ \\
\hline KK(CV) \% & 3,1 & 3,8 & 3,5 & 3,7 & 3,4 \\
\hline
\end{tabular}

Keterangan: Angka yang didampingi huruf sama pada kolom yang sama, tidak berbeda nyata pada uji BNT $5 \%$. 
Tabel 7. Rerata bobot per buah tanaman kubis $(\mathrm{kg})$

\begin{tabular}{cccccc}
\hline \multirow{2}{*}{ Mulsa } & \multicolumn{5}{c}{ Bobot buah tanaman kubis (kg) } \\
\cline { 2 - 6 } & Sehati-F1 & Daehnfeldt & Green hero & Green Coronet & KK-Cross \\
\hline Tanpa mulsa & $0,7 \mathrm{a}$ & $0,7 \mathrm{~b}$ & $0,7 \mathrm{a}$ & $0,7 \mathrm{a}$ & $0,7 \mathrm{a}$ \\
Mulsa hitam perak & $1,1 \mathrm{a}$ & $1,1 \mathrm{a}$ & $1,0 \mathrm{a}$ & $1,1 \mathrm{a}$ & $1,1 \mathrm{a}$ \\
Jerami padi & $\mathbf{1 , 2} \mathbf{a}$ & $1,0 \mathrm{a}$ & $1,1 \mathrm{a}$ & $1,0 \mathrm{a}$ & $\mathbf{1 , 2} \mathbf{a}$ \\
Sekam padi & $\mathbf{1 , 2} \mathbf{a}$ & $1,1 \mathrm{a}$ & $1,1 \mathrm{a}$ & $1,1 \mathrm{a}$ & $\mathbf{1 , 2} \mathbf{a}$ \\
\hline KK $(\mathbf{C V}) \mathbf{\%}$ & 1,5 & 1,1 & 1.0 & 1,1 & 1,2 \\
\hline
\end{tabular}

Keterangan: Angka yang didampingi huruf sama pada kolom yang sama, tidak berbeda nyata pada uji BNT 5\%.

Tabel 8. Produksi tanaman kubis (t/ha)

\begin{tabular}{cccccc}
\hline \multirow{2}{*}{$\begin{array}{c}\text { Pulsa } \\
\text { Mulch }\end{array}$} & \multicolumn{5}{c}{ Produksi tanaman (t/ha) } \\
\cline { 2 - 6 } & Sehati-F1 & Daehnfeldt & Green hero & Green Coronet & KK-Cross \\
\hline Tanpa mulsa & $11,5 \mathrm{j}$ & $20,5 \mathrm{f}$ & $10,5 \mathrm{j}$ & $13,2 \mathrm{e}$ & $17,8 \mathrm{e}$ \\
Mulsa hitam perak & $30,4 \mathrm{a}$ & $\mathbf{2 9 , 3} \mathbf{a}$ & $28,0 \mathrm{a}$ & $26,7 \mathrm{a}$ & $29 \mathrm{a}$ \\
Jerami padi & $\mathbf{3 0 , 5} \mathbf{a}$ & $26,3 \mathrm{c}$ & $\mathbf{2 8 , 8} \mathbf{a}$ & $25,4 \mathrm{a}$ & $\mathbf{3 0 , 1} \mathbf{a}$ \\
Sekam padi & $28 \mathrm{~b}$ & $25,2 \mathrm{~d}$ & $25,6 \mathrm{~b}$ & $25,6 \mathrm{a}$ & $28 \mathrm{a}$ \\
\hline KK $(\mathbf{C V}) \mathbf{\%}$ & 2,4 & 2,1 & 2,3 & 2,6 & 2,7 \\
\hline
\end{tabular}

Keterangan: Angka yang didampingi huruf sama pada kolom yang sama, tidak berbeda nyata pada uji BNT 5\%.

Selanjutnya Hermiati (2000) dalam (Marliah et al., 2013) menyatakan bahwa setiap varietas memiliki perbedaan dalam hal kemampuannya untuk mempertahankan hidup dan pertumbuhan individu dari iklim yang berbeda. Faktor genetik tanaman dan adaptasinya terhadap lingkungan menghasilkan pertumbuhan yang berbeda-beda, hal ini dapat dilihat dari varietas yang memberi pengaruh nyata terhadap pertumbuhan dan hasil Tanaman kubis.

\section{Produksi Kubis (T/Ha)}

Hasil analisis BNT menunjukkan adanya perbedaan hasil produksi pada semua perlakuan mulsa. Bobot segar krop dari kelima varietas yang diuji menunjukkan perbedaan nyata untuk setiap peubah yang diamati. Rerata produksi krop basah varietas Sehati-F1 dan KK-Cross yang tertinggi adalah 30,5 t/ha dan 30,1 t/ha pada perlakuan mulsa jerami padi, sedangkan produksi terendah adalah varietas Green hero 10,5 t/ha pada perlakuan tanpa mulsa. Hasil ini mengindikasikan bahwa dominasi sifat genetik tanaman dalam mengatur proses pertumbuhan dan produksinya masih terlihat dalam kondisi suhu sekitar tanaman berkisar antara 25 $30^{\circ} \mathrm{C}$.

Produksi tanaman sangat ditentukan oleh komponen teknologi yang digunakan. Hasil tiap varietas yang diuji pada setiap komponen berbeda nyata sedangkan antar komponen ada berbeda nyata dimana ada interaksi antara varietas yang diuji dengan mulsa yang digunakan. Varietas yang produksinya lebih tinggi dan beradaptasi terhadap lingkungan dataran rendah ditunjukkan oleh varietas Sehati-F1 dan KK-Cross. Hal ini dikemukakan Simatupang (1997) dalam (Hanny et al., 2015) bahwa tingginya produksi suatu varietas disebabkan oleh varietas tersebut mampu beradaptasi dengan lingkungan.

\section{PEMBAHASAN}

\section{Pengaruh Mulsa}

Penggunaan sekam dan jerami padi dapat berfungsi sebagai mulsa organic dapat memelihara struktur tanah, meningkatkan infiltrasi tanah, megurangi pencucian hara dan mengurangi pertumbuhan gulma (Sarief 1985 dalam Sumarni et al., 2006). Menurut Sungheningi (2012) mulsa jerami bersifat sarang dan dapat mempertahankan suhu dan kelembaban tanah (cahaya yang masuk dapat memenuhi kebutuhan tanaman untuk pertumbuhan), memperkecil penguapan air tanah sehingga tanaman yang tumbuh pada tanah tersebut dapat tumbuh dengan baik. Hal ini disebabkan karena akumulasi panas sebagai efek dekomposisi segera akan dapat ditranslokasikan ke udara, sehingga akumulasi panas dibawah mulsa dapat teratasi (stabil). Mulsa jerami menyerap air lebih banyak, dan mampu menyimpan lebih lama di banding mulsa sekam. Sebagai penyusun utama tanaman, air juga diperlukan untuk melarutkan unsur hara agar dapat tersedia bagi tanaman.

Menurut Adiningsih dalam Kasli (2008) jerami padi memiliki kandungan hara yakni bahan organik $40,87 \%$, N 1,01\%, P 0,15\%, dan K 1,75\%. Sedangkan kandungan unsur hara pada sekam padi: C-organik $(45,06 \%)$, N-total $(0,31 \%)$, P-total $(0,07 \%)$, K-total $(\mathrm{O}, 28 \%), \quad \mathrm{Ca} \quad(0,06 \mathrm{cmol}(+) / \mathrm{kg})$ dan $\mathrm{Mg} \quad(0,04$ cmol(+)/kg). Kandungan N, P, dan K pada mulsa jerami 
lebih tinggi dibanding mulsa sekam. Selain sebagai mulsa, jerami dan sekam juga dapat digunakan sebagai penambah bahan organik. Kandungan unsur hara jerami yang lebih tinggi, serta kemampuan menyerap dan menyimpan air yang lebih lama menyebabkan pertumbuhan dan perkembangan tanaman yang diberi mulsa jerami lebih optimal dibanding yang diberi mulsa sekam.

Menurut Sunghening et al. (2012) mulsa sekam yang berasal dari kulit air padi, ukurannya kecil, bersifat padat namun ringan yang berakibat sekam mudah hilang akibat terpaan angin. Sekam yang hilang mengakibatkan permukaan tanah tidak tertutupi sempurna yang berdampak pada tingginya evaporasi dibanding yang ditutupi mulsa jerami. Tingginya evaporasi menyebabkan berkurangnya lengas tanah, menghambat penyerapan unsur hara, mengganggu proses fotosintesis, sehingga pada akhirnya dapat menurunkan hasil biji kacang hijau.

Fauziati et al. (2005) telah melakukan penelitian pengaruh bahan organik dan varietas kubis di lahan lebak yang juga tidak diperoleh adanya interaksi kedua perlakuan tersebut terhadap komponen hasil tanaman kubis. Hasil yang sama juga ditemukan dalam penelitian Hadid dan Maemunah (2001) pada tanaman bawang merah. Hal yang sama juga ditemukan pada penelitian Jajang (2008) pada kultivar Kentang yang diberikan berbagai jenis mulsa. Selanjutnya menurut Hendarto dan Thamrin (1992) dalam Ramli (2010) bahwa jenis mulsa yang $\mathrm{C} / \mathrm{N}$ rasionya rendah sangat baik digunakan sebagai pupuk hijau artinya jenis mulsa ini dapat langsung dibenamkan kedalam tanah untuk memperbaiki struktur tanah dan menyiapkan unsur hara yang dibutuhkan oleh tanaman. Walaupun kenyataanya, hasil yang diperoleh akan nyata pada musim tanam berikutnya.

Penggunaan mulsa plastik hitam perak pada tanaman sayuran nyata bila suhu sekitar tanaman relatif rendah, tetapi jika suhu udara sudah mendekati optimal untuk mendukung pertumbuhan tanaman, maka fungsi mulsa plastik tidak berpengaruh nyata (Lakitan, 1995 dalam Ramli, 2010). Mulsa plastik hitam perak lebih efektif dalam mengurangi penguapan air atau transpirasi dan juga mampu memantulkan sinar matahari, sehingga ketersediaan air dan kelembaban tanah lebih optimal. Mulsa plastik hitam perak, permukaan peraknya dapat memantulkan cahaya matahari berkisar 20-30\%, sehingga cahaya yang tersedia cukup besar untuk proses fotosintesis. Warna hitam yang dimiliki menyebabkan cahaya matahari yang diteruskan sedikit, sehingga suhu tanah meningkat tetapi penguapan air tanah berkurang sehingga menguntungkan bagi tanaman. Hampir semua cahaya matahari di serap oleh bahan mulsa, yaitu $80,5 \%$ dari jumlah cahaya matahari yang datang. Cahaya matahari yang datang akan dipantulkan dalam bentuk panas ke segala arah.

\section{Pengaruh Varietas}

Beberapa varietas kubis dapat hidup pada suhu udara $10-24^{\circ} \mathrm{C}$ dengan suhu optimum $17^{\circ} \mathrm{C}$. Untuk waktu yang singkat, kebanyakan varietas kubis tahan dingin (minus $6-10^{\circ} \mathrm{C}$, tetapi untuk waktu yang lama, kubis akan rusak kecuali kubis berdaun kecil $(<3>9)$, merupakan racun bagi akar-akar tanaman. Varietas sehati F1 dan KK Cross direkomendasikan tumbuh baik pada dataran rendah-menensgah, tahan kekeringan sehingga kubis varietas ini dapat tumbuh optimal dan memperoleh hasil yang optimal juga. Varietas Green hero dan Green coronet direkomendasikan untuk dataran tinggi dengan ketinggian 700-1.700 m dpl, namun ketika ditanam di dataran rendah dengan perlakuan penggunaan mulsa plastik hitam perak, mulsa jerami, dan mulsa sekam akan memperoleh hasil produksi yang tinggi.

Rendahnya respons varietas kubis dataran rendah terhadap perlakuan mulsa sekam dan mulsa jerami diduga akibat unsur hara yang dibutuhkan kubis untuk pertumbuhannya dimanfaatkan oleh mikroorganisme tanah untuk melakukan proses dekomposisi menjadi bahan organic tanah (Ramli, 2010).

Penampakan suatu varietas akibat pengaruh lingkungan lebih disebabkan oleh lingkungan mikro tanaman dan sifat ini disebut sebagai sifat kuantitatif (Puspodarsono, 1988 dalam Ridwan et al., 2013).

\section{KESIMPULAN}

Hasil pengamatan pertumbuhan tanaman kubis menunjukkan bahwa kelima varietas yang diuji dengan penggunaan berbagai jenis mulsa sangat berpotensi untuk dibudidayakan di Maluku. Varietas dengan produksi tertinggi dan beradaptasi sangat baik terhadap lingkungan dataran rendah di Maluku adalah varietas Sehat-F1 dan KK-Cross, masing-masing dengan produksi 30,5 dan 30,1 t/ha.

Penggendalian hama dengan menggunakan pestisida nabati yang dikombinasikan dengan pengendalian secara mekanis (tampan kuning, pitfoll dan stiky trap) secara terjadwal dapat menurunkan tingkat serangan hama dan penyakit dan mengasilkan tanaman-tanaman yang sehat.

\section{DAFTAR PUSTAKA}

Ahmad, H. 2007. Laporan Hama Ulat Krop (Cloricidolomia binotalis ZELL) (Lepidoptere Pyrolidae) pada Kubis (Brassica oleracea). Dizited by IPB e-repository copy right.

Anni, I.A., E. Saptiningsih, dan S. Haryanti. 2013. Pengaruh naungan terhadap pertumbuhan dan produksi tanaman bawang daun (Allium fistulosum L.) di Bandungan, Jawa Tengah. Jurnal Biologi 2: 31-40.

Badjo, A.T., Y. Guero, N.D. Lamso, T. Idder, G. Echevarria, and T. Sterckeman. 2015. Assessment of polycyclic aromatic hydrocarbons contamination in urban soil from Niamey, Niger. Journal of Biodiversity and Environmental Sciences 6: 275-281. 
Buntoro, B.G., R. Rogomulyo, dan S. Trisnowati. 2014. Pengaruh takaran pupuk kandang dan intensitas cahaya terhadap pertumbuhan dan hasil temu putih (Curcuma zedoaria L.). Jurnal Vegetalika 3: 29-39.

Erwin, S., Ramli dan Adrianton. 2015. Pengaruh berbagai jarak tanam pada pertumbuhan dan produksi kubis (Brassica oleracea L.) di dataran menengah desa Bobo Kecamatan Palolo Kabupaten Sigi. Jurnal Agrotekbis 3: 491-497,

Fauziati, N., Y. Raihana, dan I. Riza. 2005. Pengaruh varietas dan bahan organik pada tanaman kubis di lahan lebak. Dalam: Puslitbang Tanah Agroklimat, Bogor, pp. 313-322.

Hadid, A. dan Maemunah. 2001. Pertumbuhan dan hasil tanaman bawang merah dengan modifikasi iklim mikro. Jurnal Agroland 8: 377-384.

Hanny, B.R., F. Puspita, dan Adiwirman. 2015. Uji beberapa tricho-kompos terformulasi terhadap pertumbuhan dan produksi cabai merah. JOM Faperta 2: 1-14.

Hayati, M., A. Marliah, dan H. Fajri. 2012. Pengaruh varietas dan dosis pupuk SP-36 terhadap pertumbuhan dan hasil tanaman kacang tanah (Arachis hypogaea L.). Jurnal Agrista 16: 1-13.

Herwibowo, K. dan N.S. Budiana. 2014. Hidroponic Sayuran untuk Hobi dan Bisnis. Jakarta: Penebar Swadaya.

Jajang, S.H. 2008. Pengaruh jenis mulsa terhadap pertumbuhan dan hasil tiga kultivar kentang yang di tanam di dataran medium. Jurnal Agronomi Indonesia 37: 14-20.

Kasli. 2008. Pembuatan Beberapa Pupuk Hayati Hasil Dekomposisi, accessed from <http://www.lp.unand.ac.id/?pModule=penelitia $\mathrm{n} \& \mathrm{pSub}=$ penelitian \&pAct=detail\&id137\&bi=20. 2 Februari 2012>.

Laksono, R.A. 2016. Pertumbuhan dan hasil tanaman kubis bunga (Brassica oleracea L. var. Botrytis subvar. Cauliflora DC.) kultivar Orient F1 akibat jenis mulsa dan dosis bokashi. Jurnal Agrotek Indonesia 1: 81-89.

Maluku, B.P. 2015. Maluku Dalam Angka 2014. Biro Pusat Statistik Maluku.

Marliah, A., Jumini dan Jamilah 2010. Pengaruh jarak tanam antar barisan pada sistem tumpangsari beberapa varietas jagung manis dengan kacang merah terhadap pertumbuhan dan hasil. Agrista 14: 30-38.

Marliah, A., Nurhayati, dan R. Riana. 2013. Pengaruh varietas dan konsentrasi pupuk majemuk terhadap pertumbuhan dan hasil tanaman kubis bunga (Brassica oleracea L.). Jurnal Floratek 8: 118-126.

Martin, T., F. Assogba-Komlan, T. Houndete, J. Hougard, and F. Chandre. 2006. Efficacy of mosquito netting for sustainable small holder's cabbage production in Africa. J. Econ. Entomol 99: 450-454.

Nathoo, M., R. Nowbuth, and C.L. Cangy. 1998.
Brassica production introduction and evaluation of varieties amas. Food Agriculture Research Council, Reduit, Mauritius, pp. 167-173.

Neave, S., G. Kelly, and M. Furlong. 2011. Field evaluation of insect exclusion netting for the management of pests on cabbage (Brassica oleracea var. Capitata) in Solomon Islands. Proc. the 6th Int. Workshop on Management of Diamondback Moth and Other Crucifer Insect Pests, AVRDC, Thailand, pp. 144-149.

Rahmawati, M., Hasinah HAR dan Z. Zaizuli. 2011. Pengaruh beberapa jenis pupuk dan mulsa terhadap pertumbuhan dan hasil tanaman cabai merah (Capsicum annum). Jurnal Agrista 15: 4650 .

Ramli. 2010. Respon varietas kubis (Brassica oleraceae) dataran rendah terhadap pemberian berbagai jenis mulsa. Jurnal Agroland 17: 30-37.

Ridwan, M., D.R. Rahmatu, dan R. Ali. 2013. Respons dua varietas kubis (Brassica oleracea L) terhadap berbagai jenis mulsa organik di desa langaleso kecamatan dolo. Jurnal Agroland 20: 99-104.

Salisbury, F. and C. Ross. 1995. Fisiologi Tumbuhan Jilid 2. ITB Bandung.

Sartono, J. dan S. Sartono. 2007. Kajian Insektisida Hayati Terhadap Daya Bunuh Ulat Plutella xylostell dan Crocidolomia binotalis pada Tanaman Kubis krop. Laporan Penelitian. Balai Penelitian dan Pengembangan Departemen Pertanian. Jakarta.

Sastrosiswojo, W., Setiawati, dan T. Rubiati. 2003. Selektivitas insektisida sintetik dan nabati terhadap larva Helicovarva armigera, Crocidolomia binotalis dan Spodoptera litura serta imago parasitoid Eriborus argenteopilosis. Jurnal Hortikultura 13: 251-257.

Simon, S., F.A. Komlan, L. Adjaito, A. Mensah, H.K. Coffi, M. Ngouajio, and T. Martin. 2014. Efficacy of insect nets for cabbage production and pest management depending on the net removal frequency and microclimate. International Journal of Pest Management 60: 208-216.

SPH. 2014. Statistik Produksi Hortikultura 2014. Dalam: Statistik Produksi Hortikultura 2014. p. 315.

Sumarni, N., A. Hidayat, dan E. Sumiati. 2006. Pengaruh tanaman penutup tanah dan mulsa organik terhadap produksi cabai dan erosi tanah. Jurnal Hortikultura 16: 197-201.

Sunghening, W., Tohari, and D. Shiddieq. 2012. Pengaruh mulsa organik terhadap pertumbuhan dan hasil tiga varietas kacang hijau (Vigna radiata L. Wilczek) di lahan pasir pantai Bugel, Kulon Progo. Vegetalika 1: 54 - 66.

Tang, Z.H., K.Y. Gong, and Z.P. You. 2008. Present status and control measuring of insecticide resistance in agricultural pest in Cina. Pesticide Science 23: 189-198. 